\title{
Positive Mental Health Scale: Validation of the Mental Health Continuum - Short Form
}

\author{
Wagner de Lara Machado - Pontifícia Universidade Católica de Campinas, Campinas, São Paulo, Brasil \\ Denise Ruschel Bandeira - Universidade Federal do Rio Grande do Sul, Porto Alegre, Brasil
}

\begin{abstract}
The Mental Health Continuum - Short Form (MHC-SF) is a self-reporting instrument for assessing positive mental health, which is understood as symptoms of positive affection, self-development and social connectivity. The present article describes the adaptation and validation of the MHC-SF for the Brazilian Portuguese language in a sample of 686 adults, which included $72.7 \%$ female participants and had an average age of $33.9(S D=11.30)$ years. The various methods employed to assess the MHC-SF psychometric properties (principal component analysis, factor analysis, Item Response Theory and network analysis) indicated that a unidimensional structure is sufficient to represent the structure of the instrument and its high reliability. In addition, the results showed that the individual-centered aspects of mental health are more easily manifested relative to the social-oriented aspects. The Brazilian version of the MHC-SF is a valid and reliable instrument for the assessment of positive mental health. Keywords: Mental health, well-being, exploratory factor analysis, Item Response Theory, network analysis.
\end{abstract}

\section{Escala de Saúde Mental Positiva: Validação da Mental Health Continuum - Short Form}

\begin{abstract}
Resumo
O Mental Health Continuum - Short Form (MHC-SF) é um instrumento de autorrelato para avaliação da saúde mental positiva, entendida como sintomas de afetos positivos, autodesenvolvimento e conexão social. O presente artigo apresenta a adaptação e validação deste instrumento para o Português brasileiro, uma amostra de 686 adultos, sendo $72.7 \%$ mulheres e média de idade de $33.9(S D=11.30)$ anos. Diversos métodos empregados para estimar as propriedades psicométricas do instrumento (componentes principais, análise fatorial, Teoria de Resposta ao Item, análise de rede) indicaram que uma estrutura unidimensional é suficiente para representar a estrutura do instrumento e sua alta fidedignidade. Ainda, evidenciou-se que os aspectos da saúde mental centrados na pessoa são mais facilmente manifestos em relação àqueles de orientação social. O MHC-SF em sua versão brasileira é um instrumento válido e fidedigno para avaliação da saúde mental positiva.

Palavras-chave: Saúde mental, bem-estar, análise fatorial exploratória, Teoria de Resposta ao Item, análise de rede.
\end{abstract}

\section{Escala de Salud Mental Positiva: Validación de la Mental Health Continuum - Short Form}

\begin{abstract}
Resumen
La Mental Health Continum - Short Form (MHC-SF) es un instrumento de auto relato para evaluar la salud mental positiva, que se entiende como síntomas de afecto positivo, de desarrollo personal y contexto social. El presente artículo describe la adaptación y validación del instrumento para el idioma portugués de Brasil en una muestra de 686 adultos, siendo $72.7 \%$ mujeres con edad media de 33.9 ( $S D=11,3$ ) años. Diversos métodos empleados para estimar las propiedades psicométricas del MHC-SF (análisis de componentes principales, análisis factorial, Teoría de Respuesta al Ítem y análisis de redes) indicaron que una estructura unidimensional es suficiente para representar la estructura del instrumento y su alta fiabilidad. Además, los resultados mostraron que los aspectos de salud mental centrados en el individuo son más fácilmente manifestados en relación a los aspectos de orientación social. La versión brasileña del MHC-SF es un instrumento válido y fidedigno para la evaluación de la salud mental positiva.

Palabras clave: Salud mental, bienestar, análisis factorial exploratorio, Teoría de Respuesta al Ítem, análisis de redes.
\end{abstract}

According to the definition formulated by the World Health Organization, mental health is not only characterized as the absence of mental disorders but also as "a state of well-being in which each individual realizes his or her own potential, can cope with the normal stresses of life, and is able to make a contribution to her or his community" (World Health Organization, 2005 , p. 12). In other words, mental health includes positive components, and this perspective was developed as a two continua model (Keyes, 2002). The positive dimension of mental health was operationalized by Keyes (2002, 2007; Keyes \& Lopez, 2002) as a hierarchical model with 3 interrelated second-order factors (emotional or subjective, psychological, and social well-being) and 13 first-order factors, which are described below (Diener, 1984; Gurin, Veroff, \& Feld, 1960; Jahoda, 1958; Keyes, 1998; Ryff, 1989).

According to Keyes (2006), the first attempt at systematizing the notion of positive mental health is attributed to the Austrian psychologist Marie Jahoda (1958) in her book entitled "Current Concepts of Positive Mental Health." Based on a review of the literature on personality theory and clinical psychology available at the time, Jahoda identified six components in positive 
mental health: self-acceptance, personal growth or self-actualization, integration of the self, autonomy, preserved perception of reality and environmental mastery. Soon afterward in 1960, Gurin, Veroff and Feld published a report on the mental health of citizens of the United States ("Americans view their mental health"), in which they used indicators of happiness and satisfaction with domains of life (work, family, leisure, etc.).

The studies by Jahoda (1958) and Gurin et al. (1960) produced two complementary fields of study of positive mental health: psychological well-being, which was developed by Ryff (1989), and subjective (or emotional) well-being, which was systematized by Diener (1984). Psychological well-being, which is based on the studies by Jahoda, emphasizes the development of definite individual potentialities or evolutionary tasks that occur along with development, such as possessing a positive attitude toward the self and accepting multiple aspects of one's own personality (self-acceptance); having warm, safe, intimate and satisfying relationships with others (positive relations with others); being self-determining and independent; assessing personal experiences by personal standards (autonomy); having a sense of mastery and competence in managing the environment to satisfy personal needs and values (environmental mastery); having a sense of directedness and aims and objectives for living (purpose in life); and having a feeling of continued development and openness to new experiences (personal growth) (Ryff, 1989). Subjective well-being, which is based on the studies by Gurin et al., is defined as a set of phenomena, including emotional responses, life satisfaction domains (e.g., work, leisure, family, etc.) and global judgments on life satisfaction. Subjective well-being has three main components: life satisfaction, positive affect and negative affect. Therefore, an individual with high subjective well-being is satisfied with his or her life as a whole and has frequent positive affect and infrequent negative affect (e.g., sadness, anger, etc.) (Diener, 1984).

Subsequently, Keyes (1998) enlarged the field of study of well-being by including aspects related to interpersonal and social development, which are inconsistent with the individual-centered focus of earlier models. Based on theories from philosophy, social psychology and cultural analysis, Keyes' model represents evolutionary tasks and their relationships with interpersonal experiences. The components of social well-being are the ability to demonstrate positive attitude and acceptance vis-à-vis individual differences (social acceptance); belief that society and its members are capable of evolving positively (social actualization); perception that one's activities are useful and relevant to society (social contribution); concern with and interest in society and other people (social coherence); and feeling of acceptance and support by a community (social integration).

The operationalization of positive mental health suggested by Keyes (2002) is consistent with the main components of the definition of mental health formulated by the World Health Organization, namely, feeling of well-being, effective functioning of the individual, and effective functioning within a community (Westerhof \& Keyes, 2010). Within this context, effective functioning alludes to an individual's capacity to fully utilize his or her skills and competence to satisfy his or her needs, objectives and personal and interpersonal values. This model was replicated in several studies that confirmed the latent structure of the indicators of well-being within the psychological context (Gallagher, Lopez, \& Preacher, 2009; Keyes, 2002, 2005a, 2007; Keyes, Shmotkin, \& Ryff, 2002; Linley, Maltby, Wood, Osborne, \& Hurling, 2009). The discriminant validity of the indicators of positive mental health relative to the indicators of psychopathology was assessed with exploratory and confirmatory factor analyses (Alterman et al. 2010; Keyes, 2005a; Massé et al., 1998; Peter, Roberts, \& Dengate 2011; Ryff \& Singer, 1998; Weich et al., 2011; Westerhof \& Keyes, 2010; Wilkinson \& Walford, 1998). The application of both techniques showed that the full set of indicators is better represented by a model with two oblique factors instead of models that are unidimensional and have two orthogonal factors. Therefore, the hypothesis in which mental health dimensions are juxtaposed is rejected. As a result, mental health, as a complete state, can only be investigated by considering both its positive and negative components.

\section{Psychometric Assessment of Positive Mental Health}

The Mental Health Continuum - Long Form (MHCLF) was elaborated as an instrument to assess positive mental health (Keyes, 2002), and it consists of 40 items that are distributed as follows: 7 correspond to the dimension of emotional well-being, 18 to the dimension of psychological well-being, and 15 to the dimension of social well-being. The short version of this scale (Mental Health Continuum - Short Form, MHC$\mathrm{SF}$ ) includes 14 items considered to be prototypical of the various dimensions of positive mental health, with 3 that correspond to the dimension emotional well-being, 
6 that correspond to the dimension psychological wellbeing, and 5 that correspond to the dimension social well-being (Keyes, 2005b). Originally elaborated in the United States (Keyes, 2002, 2005b), the MHC-SF was adapted for countries such as South Africa (Keyes et al. 2008), Canada (Peter, Roberts, \& Dengate 2011), the Netherlands (Westerhof \& Keyes, 2010), Italy (Petrillo, Capone, Caso, \& Keyes, 2014) and Iran (Joshanloo \& Nosratabadi, 2009).

Studies that have assessed the psychometric performance of the MHC-SF using exploratory and confirmatory factor analyses have shown that a structure with three oblique factors is the most parsimonious in explaining the set of items that compose the instrument (Keyes, 2005b; Keyes et al., 2008; Lamers, Westerhof, Bohlmeijer, ten Klooster, \& Keyes, 2011; Robitschek \& Keyes, 2009). Those studies also found that the MHCSF subscales have adequate reliability. Although the correlations among factors are moderate to strong, the results indicated that the three theoretical dimensions reported in the literature (i.e., emotional, psychological and social well-being) might be distinguished. However, a recent study by Chen, Jing, Hayes and Lee (2012), who applied a bifactor model, suggested that the indicators of emotional and psychological well-being are better explained by one general factor than by specific factors. In other words, the common variance shared by all the indicators is greater than the variance explained by specific factors. However, the bifactor model has not yet been applied to a joint investigation of the three dimensions of positive mental health.

The present article describes the adaptation and validation of the MHC-SF in a sample of Brazilian adults. Following the linguistic adaptation of the instrument, several methods were used to test its psychometric properties, including exploratory factor analysis, item response theory and network analysis. The convergent validity was assessed by performing well-being and psychopathology assessments.

\section{Method}

\section{Adaptation of the Mental Health Continum - Short Form} (MHC-SF) to the Brazilian Portuguese language

The strategy formulated for the adaptation of the MHC-SF sought to comply with the overall recommendations in the literature (Beaton, Bombardier, Guillemin, \& Ferraz, 2000; Borsa, Damásio, \& Bandeira, 2012; Geisinger, 1994; Sandoval \& Durán, 1998). Once the author of the MHC-SF provided formal consent, two bilingual translators independently translated the English version into the Brazilian Portuguese language. Subsequently, two doctors and a doctoral candidate in psychology who are bilingual and have significant experience in psychological assessment evaluated the synthesis of the two independent translations. As a result, changes in the text of five out of the 14 items in the MHC-SF were suggested. The changes suggested by the experts were performed, and then, a native English speaker performed the back-translation, which was evaluated by the author of the original version of the MHC-SF. Following changes in one single item, the final version was elaborated.

\section{Validation and psychometric properties of the Mental Health Continuum - Short Form (MHC-SF)}

\section{Participants}

The study sample consisted of 686 participants selected by convenience sampling and included 175 $(27.3 \%)$ male and $466(72.7 \%)$ female $(n=641)$ participants who had an average age of 33.9 years $(S D=$ 11.3), with the age range varying from 18 to 73 years $(n=632)$. Seven participants $(1.10 \%)$ had completed elementary school, 104 participants $(16.1 \%)$ had completed secondary school, 37 participants $(5.70 \%)$ had completed technical, training or teaching courses, 183 participants $(28.4 \%)$ had attended higher education, and 314 participants $(48.7 \%)$ had attended graduate programs $(n=645)$. The participants' places of residence were distributed across 22 Brazilian states ( $n$ = 636) (Alagoas (AL), Amazonas (AM), Bahia (BA), Ceará (CE), Espirito Santo (ES), Goiás (GO), Maranhão (MA), Minas Gerais (MG), Mato Grasso do Sul (MS), Para (PA), Paraíba (PB), Pernambuco (PE), Paraná (PR), Rio de Janeiro (RJ), Rio Grande do Norte (RN), Rondônia (RO), Rio Grande do Sul (RS), Santa Caterina (SC), Sergipe (SE), São Paulo (SP), and Tocantins (TO)) and the Federal District, mainly RS ( $n=449$; $70.6 \%)$, PR $(n=31 ; 4.9 \%)$, SP $(n=29 ; 4.6 \%)$, PB $(n=$ $27 ; 4.2 \%)$, SC $(n=26 ; 4.1 \%)$ and $\mathrm{BA}(n=15 ; 2.4 \%)$. The reported number of total participants among variables varied because of missing data.

\section{Instruments}

The Mental Health Continuum - Short Form (MHC-SF; Keyes, 2005b) consists of 14 items that are responded to on a six-point Likert scale, which ranges from "never" (1) to "every day" (6). The instrument includes three subscales that assess subjective or emotional well-being 
(three items), psychological well-being (six items) and social well-being (five items). Keyes (2005b) found reliability values of over .80 for all the subscales as well as the global scale.

The Satisfaction with Life Scale (SLS; Diener, Emmons, Larsen, \& Griffin, 1985) consists of five items that are responded to on a seven-point Likert scale, which ranges from "Strongly disagree" to "Strongly agree." Brazilian studies have reported internal consistency values from .72 to .80 (Gonçalvez \& Kapczinski, 2008; Gouveia et al., 2003).

The Psychological Well-being Scale (PWBS; Machado, Pawlowski, \& Bandeira, 2013) is adapted from Ryff and Essex's (1992) scales, and it consists of 36 items distributed across 6 subscales that assess the various dimensions of psychological well-being (positive relations with others, autonomy, environmental mastery, personal growth, purpose in life, and self-acceptance). The items are responded to on a six-point Likert scale, which ranges from "Strongly disagree" to "Strongly agree." The values of the composite reliability index of the subscales are over.70.

The Perceived Stress Scale (PSS-10; Cohen, Karmack, \& Mermelstein, 1983) is a unidimensional instrument used to evaluate stress, and it consists of 10 items, with 6 positive and 4 negative items that are responded to on a Likert frequency scale, which ranges from "never" (0) to "very often" (4). In Brazilian studies, the values of the internal consistency of the PSS ranged from .80 to .83 (Luft, Sanches, Mazo, \& Andrade, 2007; Machado, Damásio, Borsa, \& Silva, 2014).

The General Health Questionnaire (GHQ-12; Sarriera, Schwarcz, \& Câmara, 1996) consists of 12 items that are responded to on a four-point Likert scale, with the negative items ranging from 1 (not at all) to 4 (much more than usual) and the positive items ranging from 1 (more than usual) to 4 (much less than usual). Therefore, lower scores indicate a better general state of health. The value of the internal consistency of the general factor assessed by GHQ-12 is .81 (Machado, Damásio, \& Silva, 2011).

The Questionnaire for Demographic and Psychosocial Factors consists of closed-ended questions to collect data on gender, age, educational level, region, etc.

\section{Procedures}

Data collection was performed with an online questionnaire on a SurveyMonkey platform, and it was announced through social networks and e-mail lists of participants from previous studies. Secrecy and confidentiality with regards to the participants' identity were ensured and explicitly indicated on the informed consent form, which was in compliance with the National Health Council guideline 466/12 as well as with earlier guidelines. The study was approved by the research ethics committee of the Institute of Psychology, Federal University of Rio Grande do Sul (Universidade Federal do Rio Grande do Sul - UFRGS), ruling no. 89,705 on September 32012.

\section{Data Analysis}

Several techniques were used to assess the MHCSF psychometric parameters and dimensionality. A principal component analysis (Hotelling, 1933) with varimax rotation (Kaiser, 1958) was performed using software SPSS, and then, the observed eigenvalues and simulated eigenvalues were compared in a parallel analysis, with the results used as the criterion for component retention (Horn, 1965; Patil, Singh, Mishra, \& Donovan, 2008). Subsequently, an exploratory factor analysis was performed based on a polychoric correlation matrix, using Minimum Rank Factor Analysis (Shapiro \& ten Berge, 2002) as the extraction method. In addition, Promin oblique rotation (Lorenzo-Seva, 1999) was performed with the software Factor 8.1 (Lorenzo-Seva \& Ferrando, 2006). Several methods were used to establish the number of retained factors, including the Minimum Average Partial (MAP) test (Velicer, 1976), parallel analysis (PA), which utilized permutations of sample data (Timmerman \& Lorenzo-Seva, 2011), and the hull method (Lorenzo-Seva, Timmerman, \& Kiers, 2011).

The fit of models with one, two and three factors, as well as of the bifactor model (including one general and three specific factors), was assessed with a confirmatory factor analysis. A polychoric correlation matrix and the Weighted Least Squares Mean- and Variance-adjusted (WLSMV) method were used (Muthén, Du Toit, \& Spisic, 1997); this analysis was performed with the software Mplus 6.12 (Muthén \& Muthén, 2010). The goodness-of-fit indexes and corresponding reference values included the Comparative Fit Index and Tukey-Lewis Index (CFI and TLI, respectively, $\geq .95$ ), root mean square error of approximation (RMSEA, $\leq$ .05 or $\leq .08$ with a $90 \%$ confidence interval) and chi square $\left(\chi^{2}\right)$ test at statistical significance $(p \geq .05)$. A multigroup analysis was performed to investigate the invariance of factor loadings and thresholds as a function of the participants' gender.

The fit of items to the Item Response Theory Rating Scale model (Andrich, 1978) was then tested using the 
software Winsteps v. 3.72 .2 (Linacre, 2011). This model can independently assess the item difficulty parameters $(\delta)$ and latent trait level $(\theta)$ in a sample of individuals within the same linear continuum, and the results are expressed as log-odds units (logits). Although the logit scale theoretically extends to $\pm \infty$, in practice, the values tend to fall within a range of \pm 6 logits. The fit of items to the measurement method was assessed with infit and outfit residual indexes. The infit and outfit values are expected to fall within the recommended interval (.50 to 1.50), with values closer to 1.0 indicating a better explanation by the model. Local independence was assessed through the residual correlations of items, and values below $|.30|$ were expected. Differential item functioning as a function of the participants' gender was assessed by contrasting parameter difficulty between the groups. A difference equal to or less than $|.50|$ logit was used as the criterion to rule out the occurrence of differential item functioning (Linacre, 2011).

Finally, a network analysis (Borsboom \& Cramer, 2013; Schmittmann et al., 2011) was performed to investigate the pattern of relationships among the items in the MHC-SF. A network analysis is used to plot a graphic ( $\mathrm{G}$, two-dimensional) model according to the patterns of relationships among the elements in a system. The graph includes nodes that represent the analyzed variables and lines that represent the relationships between nodes. In this technique, the network architecture and dynamics are latent; thus, they are unknown. The structure of the correlations among the items in the MHC-SF was analyzed with the Fruchterman-Reingold algorithm, in which the system variables (nodes) are ordered as follows: a) after an initial state of mutual repulsion among all the variables, the variables that are mutually related are attracted; b) nodes with a greater number of relationships with the other nodes have a more central position; and c) lines represent the weighted association between nodes (e.g., correlation) such that the more intense color lines have a stronger association. The following parameters were assessed: centrality (vector extending from the most central variable in the system to the most peripheral variable), thresholds ( $\tau$, mean cutoff points and for each item), density ( $D$, ratio of the total possible and observed connections) and diameter (largest distance between two nodes). This analysis was performed with the software $\mathrm{R}$ and qgraph package (Epskamp, Cramer, Waldorp, Schmittmann, \& Borsboom, 2012). Imputation techniques were not used to compensate for missing data (approximately.1\%).

\section{Results}

Several techniques were used to assess the psychometric properties and dimensionality of the MHC-SF. Stricto sensu, a principal component analysis is not recommended for latent trait models; however, it was used in the present study to establish whether the MHC-SF items could be clustered in more parsimonious variable-index sets as a function of both the common and specific variance. Based on the Kaiser criterion, two components with eigenvalues 7.26 and 1.22 were extracted, and a PA was performed with the same number of variables and observations and 500 simulated matrixes. The second simulated eigenvalue (1.25) obtained by the PA had a higher average value than the second observed eigenvalue; therefore, only the first component should be retained, and the pattern of dimensionality observed by the exploratory factor analysis was consistent with these results. The three methods used for factor retention indicated that only the first factor exhibited lower residual variance (MAP), one common value provided a better explanation of variance compared with the factors simulated by the sample value permutations (PA), and a better proportion was observed between the fit index and degrees of freedom (hull). The criterion of unidimensionality based on the proportion between the first and second eigenvalues was also met, with the proportion of the first eigenvalue being four-fold higher than the proportion of the second eigenvalue (Hattie, 1985). The component and factor loadings of items and their corresponding reliability values are described in Table 1.

The fit to previous MHC-SF models available in the literature was tested vis-à-vis the data collected in the present study. The fit of the models with one $\left[\chi^{2}=1,033.48 d f=77, p<.001\right.$, CFI $=.91$, TLI $=$ .90$, RMSEA $=.15(90 \% \mathrm{CI}=.14-.16)]$ or two $\left[\chi^{2}\right.$ $=752.78, d f=76, p<.001, \mathrm{CFI}=.93$, TLI $=.92$, RMSEA $=.13(90 \% \mathrm{CI}=.12-.13)]$ factors was poorer than that of the model with the original three oblique factors $\left[\chi^{2}=425.95, d f=74, p<.001, \mathrm{CFI}=.96\right.$, TLI $=.96$, RMSEA $=.09(90 \% \mathrm{CI}=.08-.10)]$. In the latter, the value of the correlation between factors ranged from .72 to .83 . The bifactor model, which included one general and three specific factors $\left[\chi^{2}=195.10\right.$, $d f=63, p<.001$, CFI $=.99$, TLI $=.98$, RMSEA $=$ $.06(90 \% \mathrm{CI}=.05-.07)]$, was tested according to the results of the exploratory analysis, in which the data were adequately summarized/represented by one single component/factor, and Chen et al.'s (2012) results. The 
Table 1

Item Component and Factor Loadings and Reliability Measures of the MHC-SF

\begin{tabular}{|c|c|c|}
\hline Item (summarized content) & Component loading & Factor loading \\
\hline $1-$ Happy & .74 & .73 \\
\hline 2 - Interested & .77 & .76 \\
\hline 3 - Satisfied & .79 & .78 \\
\hline 4 - Contribute to society & .67 & .66 \\
\hline 5 - Belong to community & .68 & .67 \\
\hline 6 - Society is becoming a better place & .67 & .67 \\
\hline 7 - People are good & .68 & .65 \\
\hline 8 - Way society works makes sense & .61 & .59 \\
\hline 9 - Likes own personality & .78 & .77 \\
\hline 10 - Manages responsibility well & .72 & .69 \\
\hline 11 - Relationships with others & .74 & .71 \\
\hline 12 - Grow and become a better person & .67 & .66 \\
\hline 13 - Confident to express own ideas & .73 & .71 \\
\hline 14 - Life has direction or meaning & .78 & .80 \\
\hline Explained variance & 51.8 & Total $=56.8$ \\
\hline Reliability & $\alpha=.96$ & $\begin{array}{c}\text { Common }=70.8 \\
\omega=.93\end{array}$ \\
\hline
\end{tabular}

Note. $\alpha=$ Cronbach's alpha, $\omega=$ McDonald's omega

bifactor model exhibited remarkable incremental fit in terms of MHC-SF dimensionality, and it produced less residuals between the predicted model and empirical matrix and explained a significantly larger amount of item variance $\left(\Delta \chi^{2}=180.70, \Delta d f=11, p<.001\right)$. Differences were not observed in the item factor loadings and thresholds as a function of the participants' gender $\left[\chi^{2}=334.56, d f=202, p<.001\right.$, CFI $=.99$, TLI = .99, RMSEA $=.05(90 \%$ CI $=.04-.06)]$. The item factor loadings and reliability values in the bifactor model are described in Table 2. The item factor loadings are expressively higher in the general component, which explains approximately $50 \%$ of their variance on average. The specific factors explain a significant portion of the variance of the MHC-SF items; however, their effect is not significant $(M=17 \%)$. Therefore, the full 14-item set exhibits a greater common shared variance compared with the specific subscales.

Because general factors of positive mental health explain most of the variance among MHC-SF components, the fit of the items to the Item Response Theory Rating Scale model was tested. All the items were fit to the unidimensional measurement model, and the corresponding infit and outfit were within the recommended range (.50 to 1.50). Local dependence was not detected based on the criterion of residual correlations equal to or higher than .30. In addition, differences in the set were not observed for item endorsement odds or differential item functioning (DIF) as a function of the participants' gender. The item and person reliability values were adequate (over .70), which indicates that their order was highly reproducible (Linacre, 2011). These findings are described in Table 3 , and the items are ordered according to their degree of difficulty.

The items were located around point -.62 (SD = $.65)$ on the logit scale and had an amplitude of approximately 2.5 units (logits), which indicates that most items pose a low degree of difficulty or are inferior to the center of the linear continuum. Persons were mostly located above the central point of the scale $(M \theta=.62$, $S D=1.16$ ); thus, they exhibited higher levels of positive mental health on average. Figure 1 depicts the distribution of item and person parameters on the logit scale. The order of the items' difficulty parameter $(\delta)$ provides relevant information on the positive mental health continuum as a dimensional construct. Small clusters of characteristic items can be observed in each region of the logit scale, and they represent the typical behavior of 
Table 2

Item Factor Loadings and Reliability Measures of the MHC-SF in the Bifactor Model

\begin{tabular}{|c|c|c|c|c|}
\hline \multirow{2}{*}{ Item (summarized content) } & \multicolumn{4}{|c|}{ Factor loading } \\
\hline & General factor & EWB & SWB & PWB \\
\hline 1 - Нарpy & .70 & .65 & & \\
\hline 2 - Interested & .78 & .32 & & \\
\hline 3 - Satisfied & .78 & .36 & & \\
\hline 4 - Contribute to society & .69 & & .07 & \\
\hline 5 - Belong to community & .67 & & .23 & \\
\hline $6-$ Society is becoming a better place & .62 & & .63 & \\
\hline 7 - People are good & .62 & & .41 & \\
\hline 8 - Way society works makes sense & .57 & & .56 & \\
\hline 9 - Likes own personality & .79 & & & .21 \\
\hline 10 - Manages responsibility well & .70 & & & .19 \\
\hline 11 - Relationships with others & .72 & & & .24 \\
\hline 12 - Grow and become a better person & .62 & & & .39 \\
\hline 13 - Confident to express own ideas & .68 & & & .52 \\
\hline 14 - Life has direction or meaning & .83 & & & .12 \\
\hline Average extracted variance & .49 & .22 & .19 & .10 \\
\hline Composite reliability & .93 & .43 & .47 & .34 \\
\hline
\end{tabular}

Note. EWB = emotional well-being, $\mathrm{SWB}=$ social well-being, $\mathrm{PWB}=$ psychological well-being.

Table 3

Item Difficulty and fit, Differential Item Functioning and Reliability of the MHC-SF

\begin{tabular}{|c|c|c|c|c|}
\hline \multirow{2}{*}{ Item (summarized content) } & \multicolumn{4}{|c|}{ Rating Scale } \\
\hline & $\delta$ & Infit & Outfit & DIF* \\
\hline 8 - Way society works makes sense & .80 & 1.10 & 1.10 & .03 \\
\hline 6 - Society is becoming a better place & .50 & 1.07 & 1.05 & -.17 \\
\hline 7 - People are good & -.06 & .97 & .96 & .30 \\
\hline 4 - Contribute to society & -.32 & 1.16 & 1.20 & -.05 \\
\hline 5 - Belong to community & -.36 & 1.40 & 1.41 & .09 \\
\hline 9 - Likes own personality & -.72 & .77 & .72 & -.04 \\
\hline 3 - Satisfied & -.77 & .66 & .68 & .00 \\
\hline 10 - Manages responsibilities well & -.77 & .90 & .91 & .17 \\
\hline 13 - Confident to express own ideas & -.86 & .90 & .87 & -.45 \\
\hline 1 - Нарру & -.97 & .68 & .79 & -.15 \\
\hline 12 - Grow and become a better person & -1.01 & 1.18 & 1.16 & .23 \\
\hline 11 - Relationships with others & -1.18 & 1.08 & 1.10 & -.04 \\
\hline 14 - Life has direction or meaning & -1.29 & 1.32 & 1.14 & .05 \\
\hline 2 - Interested & -1.60 & .90 & .82 & .00 \\
\hline Mean $(S D)$ & $-.62(.65)$ & $1.01(.21)$ & $.99(.20)$ & $\begin{array}{l}.00(.18) \\
\sum=-.03\end{array}$ \\
\hline Reliability & Items $=.99$ & Persons $=.89$ & & \\
\hline
\end{tabular}

Note. $\delta=$ difficulty, DIF = parameter of difficulty contrasted between genders, $\sum=$ sum total. $*$ Reference category: man 
persons with a given latent trait level $(\theta)$. The first cluster is characterized by perceptions of personal interest and investment, desire for meaning and purpose in life, and desire for safe and warm relations with significant others. The next interval indicates feelings of happiness and satisfaction, desire for experiences of personal growth, autonomy and self-acceptance and the ability to create the environmental conditions required to satisfy personal needs. The perception of belonging and effective contribution to society and increased acceptance of and confidence in societal members are reconciled in the next region of the logit scale. The last cluster includes the belief in the ability of society to actualize itself and develop greater cohesion with individuals. Therefore, one might conclude that more person-centered characteristics (positive affect, meaning in life and self-acceptance) are more easily endorsed compared with the characteristics that have a social orientation.

Finally, we performed a network analysis to investigate the structure and dynamics of the MHC-SF items. The graphic representation $(G)$ was based on the tetrachoric correlation matrix and is depicted in Figure 2. The nodes present a summary of the item contents, and colors represent the original positive mental health dimensions. A dense system $(D=1)$ in which all the

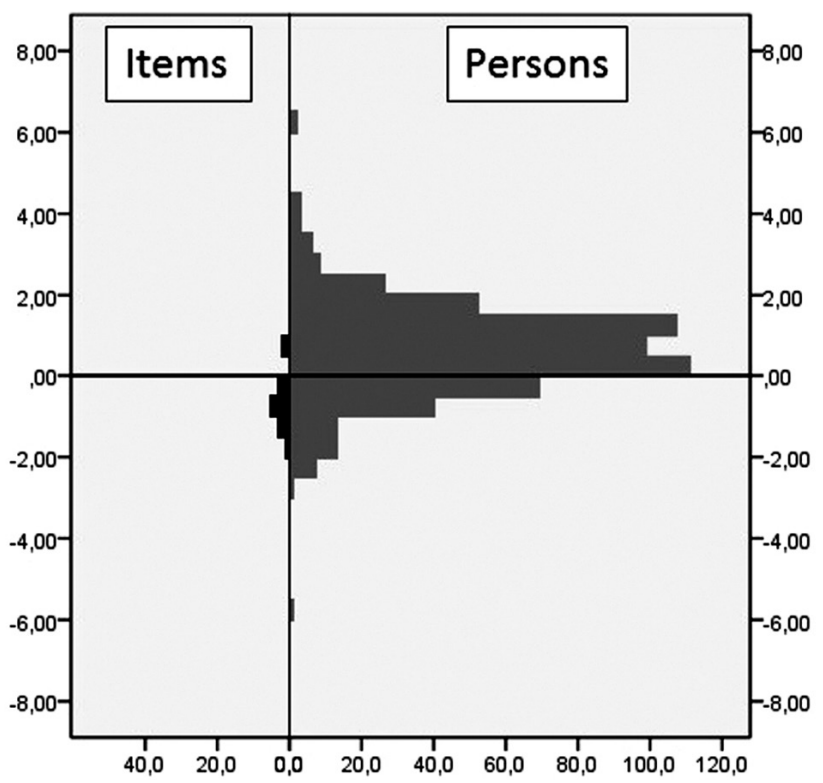

Figure 1. Map of items and persons. The vertical axis indicates the scale in logits. The distribution was obtained by fixing the contrary measure so the mean would be equal to zero. nodes are connected and moderately interrelated $\left(\mathrm{Mr}^{2}\right.$ $=.28 ; S D=.10$; diameter $[G]=.78)$ can be observed. The items exhibit a complex pattern of association because they are not necessarily clustered per dimension or specific subscale.

Certain items exhibit greater association with items at a subscale other than their own, such as the items “interested," “contribution," “acceptance," "mastery" and "purpose." The most central items are "purpose," "satisfaction," "self-acceptance" and "interested," which indicates that they are generally more correlated with the remainder of the items on the same scale. The items' centrality and threshold $(\tau)$ values are described in Table 4.

Spearman's rank correlation analysis (rho) was performed to investigate the association of the total MHC-SF score with specific dimensions (emotional, social and psychological well-being) as well as with the scales for the SLS, PWBS, PSS-10 and GHQ-12. The aim of that analysis was to investigate the convergent validity of the MHC-SF because positive associations with well-being variables (SLS, PWBS) and negative associations with psychopathology variables (PSS10, GHQ-12) were expected. As shown in Table 5, all the correlations were significant and exhibited the expected direction. After analyzing the correlations for specific factors, the patterns of correlation remained unaltered.

\section{Discussion}

All the techniques (principal component analysis, exploratory and confirmatory factor analysis, item response theory and network analysis) employed to assess the psychometric properties of the MHC-SF indicated a structure that was unidimensional or had one general component/factor with a greater ability to explain the dynamics of the interrelationship among items (Chen et al., 2012). Similarly, an analysis of the correlation of the total MHC-SF score with the original subscales and criterion variables showed similar patterns of association, which indicates that the use of the unidimensional measure does not involve a loss of information. The scale reliability was assessed by four different methods (Cronbach's alpha, McDonald's omega, composite reliability and item reliability in the Item Response Theory Rating Scale model), and the results showed little systematic variance or error variance in the scores and indicated high reproducibility in the order of items. 


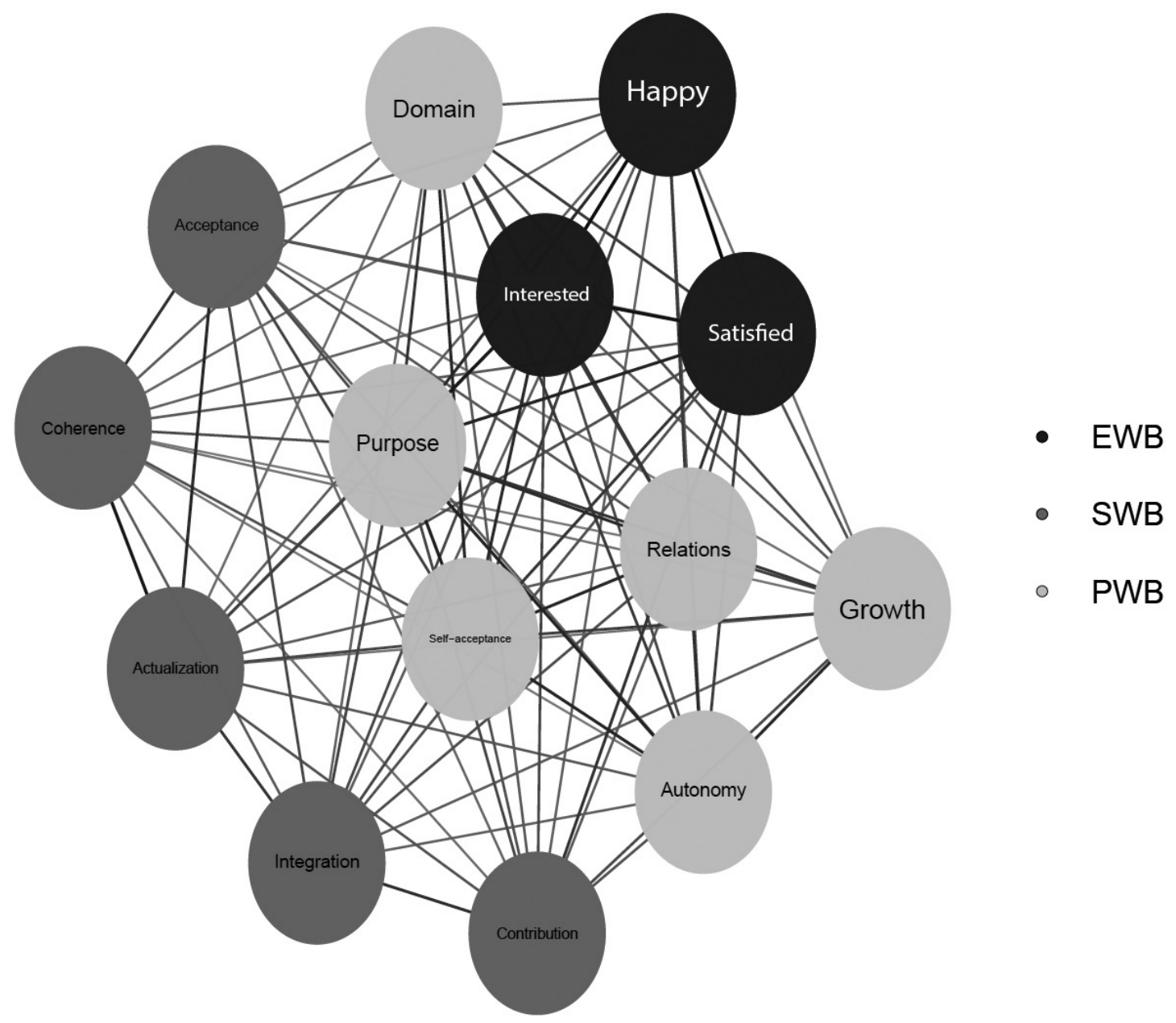

Figure 2. Network of positive mental health indicators. The covariance structure indicates that the MHC-SF items are strongly associated with the others, resulting in a dense component. The items in the emotional (EWB), social (SWB) and psychological (PWB) well-being subscales exhibit moderate to strong crossed associations. Purpose in life and self-acceptance are the central nodes of the system, meaning that they are more strongly associated with the remainder of the items. The stronger line represents the correlation between "happy" and "satisfied" $\left(r_{1-3}=.78\right)$; the fainter line represents the correlation between "relations" and "coherence" $\left(r_{8-11}=.35\right)$.

One further relevant finding is that regardless of the method used for assessment, the estimated parameters exhibited remarkable stability. Thus, both the component and factor loadings in the exploratory and confirmatory factor analyses and centrality in the network analysis indicated that the central items in the MHC-SF, "purpose and meaning in life," "satisfied," "likes his/her personality" and "interested," were the most relevant. Although their interpretation, including their weight, linear relationship between items and factors, and strength of association with the remainder of the nodes in the system, differed among the various techniques, the results were consistent: these items have the optimal ability to discriminate between levels of positive mental health. The average correlation between the estimates was $M r=.96$, and such congruence was also found relative to the item difficulty parameter. The values resulting from the Item Response Theory Rating Scale model $(\delta)$ and item tetrachoric matrix $(\tau)$ indicated nearly the same order of items $(r=.99)$.

Our findings and interpretations are not inconsistent with or intended to modify the well-consolidated theory on positive mental health and its indicators (Gallagher et al., 2009; Keyes, 2002, 2005a, 2007; Keyes et al., 2002; Linley et al., 2009); rather, they are only meant to place the theory into perspective. Within this context, 
Table 4

Centrality Indexes and Thresholds of the Network Elements

\begin{tabular}{lcc}
\hline Item (summarized content) & Centrality eigenvector* & $\tau$ \\
\hline 1 - Happy & .90 & -.77 \\
2 - Interested & .96 & -1.12 \\
3 - Satisfied & .97 & -.57 \\
4 - Contribute to society & .84 & -.24 \\
5 - Belong to community & .85 & -.26 \\
6- Society is becoming a better place & .85 & .31 \\
7 - People are good & .83 & -.08 \\
8 - Way society works makes sense & .79 & .53 \\
9 - Likes own personality & .97 & -.54 \\
10 - Manages responsibility well & .87 & -.59 \\
11 - Relationships with others & .90 & -.81 \\
12 - Grow and become a better person & .82 & -.74 \\
13 - Confident to express own ideas & .89 & -.67 \\
$14-$ Life has direction or meaning & 1.00 & -.80 \\
\hline
\end{tabular}

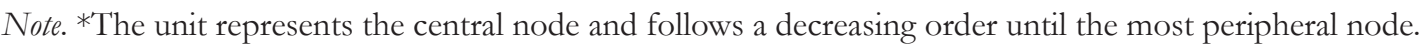

Table 5

Correlation of the MHC-SF with Criterion Variables and Descriptive Statistics of Indicators

\begin{tabular}{|c|c|c|c|c|c|c|c|c|c|}
\hline & LSS & PR & $\mathrm{AU}$ & EM & PG & PL & SA & PSS & GHQ \\
\hline MHC-SF & .63 & .52 & .26 & .56 & .53 & .69 & .66 & -.60 & -.60 \\
\hline EWB & .65 & .46 & .25 & .50 & .49 & .65 & .65 & -.60 & -.65 \\
\hline SWB & .46 & .44 & .16 & .39 & .39 & .52 & .47 & -.44 & -.41 \\
\hline PWB & .60 & .51 & .32 & .62 & .55 & .69 & .68 & -.61 & -.61 \\
\hline $\mathrm{N}$ & 463 & 414 & 425 & 415 & 429 & 420 & 414 & 403 & 403 \\
\hline$\alpha$ & .91 & .78 & .67 & .82 & .80 & .85 & .85 & .87 & .93 \\
\hline
\end{tabular}

Note. All the correlations are statistically significant at $p \leq .01$. The number of cases varies from 403 to 463 because of missing data. MHC-SF = Mental Health Continum - Short Form; EWB = emotional well-being; SWB = social well-being; PWB = psychological well-being; LSS = Life Satisfaction Scale; PR = positive relations with others; AU= autonomy; EM = environmental mastery; PG = personal growth PL = purpose in life; SA = self-acceptance; PSS = Perceived Stress Scale; GHQ = General Health Questionnaire; $M=$ mean; $S D=$ standard deviation; $\alpha=$ Cronbach's alpha.

analysis of the item difficulty parameters $(\delta, \tau)$ revealed a relevant feature: the person-centered elements of positive mental health are more easily perceived/endorsed than the elements related to social orientation. We suggest that the original three-factor structure reflects sets of items as a function of their degree of difficulty, and similar interactions between various psychometric parameters are well known (Bond, 1994; Ferguson,
1941; Guilford, 1941; Van der Ven \& Ellis, 2000). In the case of the MHC-SF, this interaction was expressed by the negative correlation among measures related to the parameters of discrimination (weight, factor loading, centrality, etc.) and parameters of item difficulty $(\delta, \tau)$ $(M r=-.72)$. Thus, the easier items are more correlated with all the others, whereas the more difficult items are less correlated with the total set of items, and items 
with similar parameters of item difficulty are more correlated with the other items compared with items with less similar parameters. This hypothesis explains why previous studies (e.g., Keys, 2005b; Keyes et al., 2008; Lamers et al., 2011; Petrillo et al., 2014; Westerhof \& Keyes, 2010) found that the average scores on the subscale social well-being were lower compared with the scores on the subscales emotional and psychological well-being after the MHC-SF items were separated across different factors. Separating indicators across factors also involves dividing the common shared variance, which might result in biased interpretations of the relationship between positive mental health and other relevant variables (e.g., maximizing, minimizing, or even suppressing current relationships).

\section{Conclusion}

The MHC-SF is a self-reporting instrument that assesses positive mental health using 13 indicators (14 items) of psychological well-being. In the present study, several analyses were used (principal component analysis, factor analysis, item response theory and network analysis) to test the psychometric properties of the Brazilian Portuguese version of the MHC-SF. In addition, correlations between the MHC-SF and indicators of well-being and psychopathology were assessed. The results indicated that the MHC-SF represents a valid and reliable measurement of positive mental health according to the model formulated by Keyes (2002), and the study provided relevant information on the dimensionality of the MHC-SF and characteristic behavior of the construct dimensional continuum. Therefore, we have concluded that the MHC-SF might be parsimoniously represented by a unidimensional structure and suggest that individual-centered behaviors are more easily endorsed compared with socially oriented behavior. These results were consistent when the participants were compared per gender.

Certain limitations of the present study are deserving of mention. A non-probabilistic sample was used, and it increases the odds of type I error inflation. Although we applied several strategies in our investigative approach and used robust techniques to improve the safety of our inferences, studies with larger and probabilistic samples should be performed to verify our results and conclusions. In addition, the gender distribution of the sample was not ideal. Thus, the results of our multigroup and differential item functioning analyses should be confirmed by future studies with more balanced samples relative to gender, educational level, geographical distribution and socioeconomic level. A further limitation was caused by the narrow socioeconomic range of the participants. Because many indicators of well-being are correlated with such variables, studies assessing the psychometric properties of the MHC-SF in samples with lower socioeconomic levels are required. Finally, we believe that future studies should also investigate the association of positive mental health with the variables related to that process, such as personality traits, age, gender, health biological markers, self-care habits, spirituality/ religiousness, etc.

The final adapted version of the MHC-SF, named the Positive Mental Health Scale, is described in Appendix A. The raw scores of the scale might be used as indicators of positive mental health levels; however, we recommend using modeled scores (factor analysis and item response theory) whenever possible. A normative table that includes the samples from the present study and raw and modeled scores is presented at the end of the article (Appendix B). Although previous authorization is not required to use the Positive Mental Health Scale, we do require that proper credit be given to its authors and the present article be cited as a reference.

\section{References}

Alterman, A. I., Cacciola, J. S., Ivey, M. A., Coviello, D. M., Lynch, K. G., Dugosh, K. L., \& Habing, B. (2010). Relationship of mental health and illness in substance abuse patients. Personality and Individual Differences, 49(8), 880-884.

Andrich, D. (1978). A rating formulation for ordered response categories. Psychometrika, 43(4), 561-573.

Beaton, D. E., Bombardier, C., Guillemin, F., \& Ferraz, M. B. (2000). Guidelines for the process of cross-cultural adaptation of self-report measures. SPINE, 24, 3186-3191.

Bond T. G. (1994). Too many factors in Factor Analysis? Rasch Measurement Transactions, 8(1), 347.

Borsa, J. C., Damásio, B. F., \& Bandeira, D. R. (2012) Adaptação e validação de instrumentos psicológicos entre culturas: Algumas considerações. Paidéia, 22(53), 423-432.

Borsboom, D., \& Cramer, A. O. J. (2013). Network analysis: An integrative approach to the structure 
of psychopathology. Annual Review of Clinical Psychology, 9, 91-121.

Chen, F. F., Jing, Y., Hayes, A., \& Lee, J. M. (2012). Two concepts or two approaches? A bifactor analysis of psychological and subjective well-being. Journal of Happiness Studies, 14(3), 1033-1068.

Cohen, S., Karmack. T., \& Mermelsteinm, R. (1983). A global measure of perceived stress. Journal of Health and Social Behavior, 24(4), 385-396.

Damásio, B. F., Machado, W. L., \& Silva, J. P. (2011). Estrutura fatorial do questionário de saúde geral (QSG-12) em uma amostra de professores escolares. Avaliação Psicológica, 10(1), 99-105.

Diener, E. (1984). Subjective well-being. Psychological Bulletin, 95(3), 542-575.

Diener, E., Emmons, R. A., Larsen, R., \& Griffin, S. (1985). The satisfaction with life scale. Journal of Personality Assessment, 49(1), 91-95.

Epskamp, S., Cramer, A. O. J., Waldorp, L. J., Schmittmann, V. D., \& Borsboom, D. (2012). Qgraph: Network visualizations of relationships in psychometric data. Journal of Statistical Software, 48, 1-18.

Ferguson G. A. (1941). The factorial interpretation of test difficulty. Psychometrika, 6(5), 323-329.

Gallagher, M. W., Lopez, S. J., \& Preacher, K. J. (2009). The hierarchical structure of well-being. Journal of Personality, 77(4), 1025-1050.

Geisinger, K. F. (1994). Cross-cultural normative assessment: Translation and adaptation issues influencing the normative interpretation of assessments instruments. Psychological Assessment, 6(4), 304-312.

Gonçalves, D. M., \& Kapczinski, F. (2008). Transtorno mental, indicadores demográficos e satisfação com a vida. Revista de Saúde Pública, 42(6), 1060-1066.

Gouveia, V. V., Chaves, S. S. S., Oliveira, I. C. P., Dias, M. R., Gouveia, R. S. V., \& Andrade, P. R. (2003). A utilização do QSG-12 na população geral: Estudo de sua validade de construto. Psicologia: Teoria e Pesquisa, 19(3), 241-248.

Guilford J. P. (1941). The difficulty of a test and its factor composition. Psychometrika 6(2), 67-77.

Gurin, G., Veroff, J., \& Feld, S. (1960). Americans view their mental health. New York: Basic Books.
Hattie, J. (1985). Methodology review: Assessing unidimensionality of tests and itens. Applied Psychological Measurement, 9(2), 139-164.

Holgado-Tello, F., Chacón-Moscoso, S., Barbero-García, I., \& Vila-Abad, E. (2010). Polychoric versus Pearson correlations in exploratory and confirmatory factor analysis of ordinal variables. Quality and Quantity, 44, 153-166.

Horn, J. L. (1965). A rationale and test for the number of factors in factor analysis. Psychometrika, 30, 179-85.

Hotelling, H. (1933). Analysis of complex statistical variables into principal components. Journal of $E d-$ ucational Psychology, 24(6), 417-441.

Jahoda, M. (1958). Current concepts of positive mental health. New York, NY: Basic Books.

Joshanloo, M., \& Nosratabadi, M. (2009). Levels of mental health continuum and personality traits. Social Indicators Research, 90(2), 211-224.

Kaiser, H. F. (1958). The varimax criterion for analytic rotation in factor analysis. Psychometrika, 23(3), 187-200.

Keyes, C. L. M. (1998). Social well-being. Social Psychology Quarterly, 61(2), 121-140.

Keyes, C. L. M. (2002). The mental health continuum: From languishing to flourishing in life. Journal of Health and Social Research, 43(2), 207-222.

Keyes, C. L. M. (2005a). Mental illness and/or mental health? Investigating axioms of the complete state model of health. Journal of Counseling and Clinical Psychology, 73(3), 539-548.

Keyes, C. L. M. (2005b). The subjective well-being of America's youth: Toward a comprehensive assessment. Adolescent and Family Health, 4, 3-11.

Keyes, C. L. M. (2006). Subjective well-being in mental health and human development research worldwide: An introduction. Social Indicators Research, 77, 1-10.

Keyes, C. L. M. (2007). Promoting and protecting mental health as flourishing: A complementary strategy for improving national mental health. American Psychologist, 62(2), 95-108.

Keyes, C. L. M., \& Lopez, S. J. (2002). Toward a science of mental health: Positive directions in diagnosis 
and interventions. In C. R. Snyder \& S. J. Lopez (Eds.), Handbook of positive psychology (pp. 45-62). New York, NY: Oxford University Press.

Keyes, C. L. M., Shmotkin, D., \& Ryff, C. D. (2002). Optimizing well-being: The empirical encounter of two traditions. Journal of Personality and Social Psychology, 82(6), 1007-1022.

Keyes, C. L. M., Wissing, M., Potgieter, J.P., Temane, M., Kruger, A., \& van Rooy, S. (2008). Evaluation of the mental health continuum - short form (MHC$\mathrm{SF}$ ) in Setswana-speaking South Africans. Clinical Psychology and Psychotherapy, 15(3), 181-192.

Lamers, S. M. A., Westerhof, G. J., Bohlmeijer, E. T., ten Klooster, P. M., \& Keyes, C. L. M. (2011). Evaluating the psychometric properties of the mental health continuum - short form (MHC-SF). Journal of Clinical Psychology, 67(1), 99-110.

Linacre, J. M. (2011). A user's guide to winsteps, program manual 3.74.0. Chicago: Winsteps.com.

Linley, A., Maltby, J., Wood, A. M., Osborne, G., \& Hurling, R. (2009). Measuring happiness: The higher order factor structure of subjective and psychological well-being measures. Personality and Individual Differences, 47(8), 878-884.

Lorenzo-Seva, U. (1999). Promin: A method for oblique factor rotation. Multivariate Behavioral Research, 34(3), 347-365.

Lorenzo-Seva, U., \& Ferrando, P. J. (2006). Factor: A computer program to fit the exploratory factor analysis model. Behavior Research Methods, 38(1), 88-91.

Lorenzo-Seva, U., Timmerman, M. E., \& Kiers, H. A. L. (2011). The hull method for selecting the number of common factors. Multivariate Behavioral Research, 46(2), 340-364.

Luft C. B., Sanches S. O., Mazo, G. Z., \& Andrade A. (2007). Versão brasileira da escala de estresse percebido: Tradução e validação para idosos. Revista de Saúde Pública, 41(4), 606-615.

Machado, W. L., Damásio, B. F., Borsa, J. C., \& Silva, J. P. (2014). Dimensionalidade da escala de estresse percebido (Perceived Stress Scale, PSS-10) em uma amostra de professores. Psicologia: Reflexão e Crítica, 27 (1), 38-43.

Machado, W. L., Pawlowski, J., \& Bandeira, D. R. (2013). Validação da psychological well-being scale em uma amostra de estudantes universitários. Avaliação Psicológica, 12(2), 263-272.

Massé, R., Poulin, C., Dassa, C., Lambert, J., Bélair, S., \& Battaglini, A. (1998). The structure of mental health: Higher-order confirmatory factor analyses of psychological distress and well-being measures. Social Indicators Research, 45(1-3), 475-504.

Muthén, B., Du Toit, S. H. C., \& Spisic, D. (1997). Robust inference using weighted least squares and quadratic estimating equations in latent variable modeling with categorical and continuous outcomes. Non-published technical report.

Muthén, L. K., \& Muthén, B. O. (2010). Mplus: Statistical analysis with latent variables. User's guide. Los Angeles: Muthén \& Muthén.

Patil, V. H., Singh S. N., Mishra S., \& Donovan, T. (2008). Efficient theory development and factor retention criteria: A case for abandoning the "eigenvalue greater than one" criterion. Journal of Business Research, 61(2), 162-170.

Peter, T., Roberts, L. W., \& Dengate, J. (2011). Flourishing in life: An empirical test of the dual continua model of mental health and mental illness among Canadian university students. The International Journal of Mental Health Promotion, 13(1), 13-22.

Petrillo, G., Capone, V., Caso, D., \& Keyes, C. L. M. (2014). The mental health continuum short-form (MHC-SF) as a measure of well-being in the Italian context. Social Indicators Research, 22, 1-22.

Robitschek, C., \& Keyes, C. L. M. (2009). Keyes's model of mental health with personal growth initiative as a parsimonious predictor. Journal of Counseling Psychology, 56(2), 321-329.

Ryff, C. D. (1989). Happiness is everything, or is it? Explorations on the meaning of psychological well-being. Journal of Personality and Social Psychology, 57(6), 1069-108.

Ryff, C. D., \& Essex, M. J. (1992). The interpretation of life experience and well-being: The sample case of relocation. Psychology and Aging, 7(4), 507-517.

Ryff, C. D., \& Singer B. H. (1998). The contours of positive human health. Psychological Inquiry, 9(1), $1-28$.

Sandoval, J., \& Durán, R.P. (1998). Language. In J. Sandoval, C. L. Frisby, K. F. Geisinger, J. D. 
Sheuneman \& J. R. Grenier (Eds.), Test interpretation and diversity: Achieving equity in assessment wording (pp. 181-211). Washington, DC: American Psychological Association.

Sarriera, J. C., Schwarcz, C., \& Câmara, S. G. (1996). Bem-estar psicológico: Análise fatorial da escala de Goldberg (GHQ-12) numa amostra de jovens. Psicologia: Reflexão e Crítica, 9(2), 293-306.

Schmittmann, V. D., Cramer, A. O. J., Waldorp, L. J., Epskamp, S., Kievit, R. A., \& Borsboom, D. (2013). Deconstructing the construct: A network perspective on psychological phenomena. New Ideas in Psychology. doi: 10.1016/j. newideapsych.2011.02.007

Shapiro, A., \& ten Berge, J. M. F. (2002). Statistical inference of minimum rank factor analysis. Psychometrika, 67(1), 79-94.

Timmerman, M. E., \& Lorenzo-Seva, U. (2011). Dimensionality assessment of ordered polytomous items with parallel analysis. Psychological Methods, 16, 209-220.

Van der Ven, A. H. G. S., \& Ellis, J. L. (2000). A Rasch analysis of Raven's standard progressive matrices. Personality and Individual Differences, 29(1), 45-64.
Velicer,W. F. (1976). Determining the number of components from the matrix of partial correlations. Psychometrika, 41, 321-327.

Weich, S., Brugha, T., King, M., McManus, S., Beddington, P., Jenkins, R., Cooper, C., McBride, O., \& Stewart-Brown, S. (2011). Mental well-being and mental illness: Findings from the adult psychiatric morbidity survey for England 2007. The British Journal of Psychiatry, 199, 23-28.

Westerhof, G. J., \& Keyes, C. L. M. (2010). Mental illness and mental health: The two continua model across the lifespan. Journal of Adult Development, 17(2), 110-119.

Wilkinson, R. B., \& Walford, W. A. (1998). The measurement of adolescent psychological health: One or two dimensions? Journal of Youth and Adolescence, 27(4), 443-455.

World Health Organization. (2005). Promoting mental bealth: Concepts, emerging evidence, practice. Geneva: WHO.

Recebido: 06/06/2014 $1^{a}$ reformulação: 19/08/2014

Aprovado: 08/11/2014

Nota dos autores:

Coordenação de Aperfeiçoamento de Pessoal de Nível Superior (CAPES), Ministério da Educação, funded this research during the first author doctoral and postdoctoral fellow.

Sobre os autores:

Denise Ruschel Bandeira é doutora em Psicologia, professora dos cursos de graduação e pós-graduação em Psicologia da UFRGS, pesquisadora 1C do CNPq e atual coordenadora do Programa de Pós-Graduação em Psicologia da UFRGS.

Wagner de Lara Machado é doutor em Psicologia, professor dos cursos de graduação e pós-graduação em Psicologia da Pontifícia Universidade Católica de Campinas (PUC-Campinas).

\section{Contato com os autores:}

Pontifícia Universidade Católica de Campinas (PUC-Camp)

Campus II - Av. John Boyd Dunlop, s/n. ${ }^{\circ}$ Jd. Ipaussurama, Campinas - SP

CEP: 13060-904

E-mail:wagner.machado@puc-campinas.edu.br 


\section{Appendix A}

Escala de Saúde Mental Positiva (Machado \& Bandeira, 2015)

Por favor, responda às questões a seguir sobre como você tem se sentido durante o último mês. Assinale a resposta que melhor representa a frequência com que você teve a experiência ou sentiu-se da maneira descrita.

Durante o último mês, com que frequência você sentiu:

\begin{tabular}{|c|c|c|c|c|c|c|c|c|c|c|}
\hline \multirow[t]{2}{*}{$\begin{array}{c}1 \\
\text { Nunca }\end{array}$} & \multirow[t]{2}{*}{$\begin{array}{c}2 \\
\text { Uma ou duas } \\
\text { vezes }\end{array}$} & \multirow[t]{2}{*}{$\begin{array}{c}3 \\
\text { Cerca de uma } \\
\text { vez por semana }\end{array}$} & \multirow[t]{2}{*}{$\begin{array}{c}4 \\
\text { Cerca de } 2 \text { ou } \\
3 \text { vezes por } \\
\text { semana } \\
\end{array}$} & \multicolumn{3}{|c|}{$\begin{array}{c}5 \\
\text { Quase todos os } \\
\text { dias }\end{array}$} & \multicolumn{4}{|c|}{$\begin{array}{c}6 \\
\text { Todos os dias }\end{array}$} \\
\hline & & & & & 1 & 2 & 3 & 4 & 5 & 6 \\
\hline \multicolumn{5}{|l|}{ Feliz. } & & & & & & \\
\hline \multicolumn{5}{|c|}{ Interessada(o) pela vida. } & & & & & & \\
\hline \multicolumn{5}{|l|}{ Satisfeito(a). } & & & & & & \\
\hline \multicolumn{5}{|c|}{ Que você teve algo importante para contribuir para a sociedade. } & & & & & & \\
\hline \multicolumn{5}{|c|}{ Que você pertencia a uma comunidade (como um grupo social ou sua vizinhança). } & & & & & & \\
\hline \multicolumn{5}{|c|}{ Que nossa sociedade está se tornando um lugar melhor para pessoas como você. } & & & & & & \\
\hline \multicolumn{5}{|c|}{ Que as pessoas, em geral, são boas. } & & & & & & \\
\hline \multicolumn{5}{|c|}{ Que a forma como a nossa sociedade funciona faz sentido para você. } & & & & & & \\
\hline \multicolumn{5}{|c|}{ Que você gostava da maior parte de suas características de personalidade. } & & & & & & \\
\hline \multicolumn{5}{|c|}{ Que você administrou bem as responsabilidades do seu dia a dia. } & & & & & & \\
\hline \multicolumn{5}{|c|}{ Que você tinha relacionamentos afetuosos e de confiança com outras pessoas. } & & & & & & \\
\hline \multicolumn{5}{|c|}{ Que você teve experiências que o desafiaram a crescer e tornar-se uma pessoa melhor. } & & & & & & \\
\hline \multicolumn{5}{|c|}{ Que você foi confiante para pensar ou expressar suas ideias e opiniões próprias. } & & & & & & \\
\hline Que sua vida & propósito ou & sentido. & & & & & & & & \\
\hline
\end{tabular}




\section{Appendix B}

Positive Mental Health Scale (Machado \& Bandeira, 2015)

Normative table

\begin{tabular}{|c|c|c|c|c|c|}
\hline Raw score & Modeled score (Rasch) & Percentile & Raw score & Modeled score (Rasch) & Percentile \\
\hline 14 & -5.75 & 1 & 50 & -0.03 & 25 \\
\hline 15 & -4.51 & 1 & 51 & 0.02 & 27 \\
\hline 16 & -3.77 & 1 & 52 & 0.09 & 29 \\
\hline 17 & -3.32 & 1 & 53 & 0.15 & 31 \\
\hline 18 & -2.99 & 1 & 54 & 0.21 & 32 \\
\hline 19 & -2.73 & 1 & 55 & 0.27 & 35 \\
\hline 20 & -2.51 & 1 & 56 & 0.34 & 38 \\
\hline 21 & -2.32 & 1 & 57 & 0.40 & 42 \\
\hline 22 & -2.16 & 1 & 58 & 0.47 & 44 \\
\hline 23 & -2.01 & 2 & 59 & 0.54 & 47 \\
\hline 24 & -1.88 & 2 & 60 & 0.61 & 50 \\
\hline 25 & -1.76 & 2 & 61 & 0.69 & 54 \\
\hline 26 & -1.66 & 3 & 62 & 0.76 & 57 \\
\hline 27 & -1.55 & 4 & 63 & 0.84 & 59 \\
\hline 28 & -1.46 & 4 & 64 & 0.92 & 62 \\
\hline 29 & -1.37 & 4 & 65 & 1.01 & 65 \\
\hline 30 & -1.29 & 5 & 66 & 1.09 & 68 \\
\hline 31 & -1.21 & 5 & 67 & 1.19 & 71 \\
\hline 32 & -1.14 & 6 & 68 & 1.28 & 74 \\
\hline 33 & -1.07 & 6 & 69 & 1.38 & 78 \\
\hline 34 & -1.00 & 7 & 70 & 1.49 & 81 \\
\hline 35 & -0.93 & 7 & 71 & 1.60 & 84 \\
\hline 36 & -0.86 & 8 & 72 & 1.72 & 87 \\
\hline 37 & -0.80 & 9 & 73 & 1.85 & 89 \\
\hline 38 & -0.74 & 10 & 74 & 1.99 & 91 \\
\hline 39 & -0.68 & 11 & 75 & 2.14 & 93 \\
\hline 40 & -0.62 & 12 & 76 & 2.30 & 94 \\
\hline 41 & -0.56 & 13 & 77 & 2.49 & 95 \\
\hline 42 & -0.50 & 14 & 78 & 2.70 & 97 \\
\hline 43 & -0.44 & 15 & 79 & 2.94 & 97 \\
\hline 44 & -0.38 & 16 & 80 & 3.22 & 98 \\
\hline 45 & -0.33 & 18 & 81 & 3.58 & 99 \\
\hline 46 & -0.27 & 19 & 82 & 4.05 & 99 \\
\hline 47 & -0.21 & 20 & 83 & 4.82 & 99 \\
\hline 48 & -0.15 & 21 & 84 & 6.07 & 99 \\
\hline 49 & -0.09 & 23 & & & \\
\hline
\end{tabular}

Note. In the Rasch score, the items average was fixed to zero. 